\title{
Net ion fluxes and ammonia excretion during transport of Rhamdia quelen juveniles
}

\author{
Fluxo de íons e excreção de amônia durante o transporte juvenis de Rhamdia quelen
}

\section{Luciano de Oliveira Garcia ${ }^{\mathrm{I}}$ Leonardo José Gil Barcellos ${ }^{\mathrm{II}}$ Bernardo Baldisserotto ${ }^{\mathrm{III}}$}

\begin{abstract}
The objective of this study was to verify net ion fluxes and ammonia excretion in silver catfish transported in plastic bags at three different loading densities: 221, 286 and $365 \mathrm{~g} \mathrm{~L} \mathrm{~L}^{-1}$ for $5 \mathrm{~h}$. A water sample was collected at the beginning and at the end of the transport for analysis of water parameters. There was a significant positive relationship between net ion effluxes and negative relationship between ammonia excretion and loading density, demonstrated by the following equations: $\mathrm{Na}^{+}: y-24.5-0.27 x, \mathrm{r}^{2}=0.99, \mathrm{Cl}^{-}$: $y=40.2-0.61 x, r^{2}=0.98, K^{+}: y=8.0-27.6 x, r^{2}=0.94$; ammonia excretion: $y=-11.43+0.017 x, r^{2}=0.95$, where $y$ : net ion flux (mmol $\mathrm{kg}^{-1} \mathrm{~h}^{-1}$ ) or ammonia excretion $\left(\mathrm{mg} \mathrm{kg}^{-1} \mathrm{~h}^{-1}\right)$ and $x$ : loading density ( $\mathrm{g}$ ). Therefore, the increase of loading density increases net ion loss, but reduces ammonia excretion during the transport of silver catfish, indicating the possibility of ammonia accumulation.
\end{abstract}

Key words: fish transport, ionoregulation, load density.

\section{RESUMO}

O objetivo deste estudo foi verificar ofluxo de ions e a excreção de amônia em jundiás transportados em sacos plásticos em três diferentes densidades de carga: 221, 286 e $365 \mathrm{~g} \mathrm{~L}^{-1}$ por $5 \mathrm{~h}$. Uma amostra de água foi coletada no início e ao final do transporte para as análises dos parâmetros de qualidade da água. Houve uma relação positiva significativa entre o efluxo de ions e relação negativa entre excreção de amônia e densidade de carga, demonstrada pelas seguintes equações: $\mathrm{Na}^{+}: y=-24.5-0.27 x, r^{2}=0.99, \mathrm{Cl}^{-}: y=40.2-0.61 x$, $r^{2}=0.98, K^{+}: y=8.0-27.6 x, r^{2}=0.94$; excreção de amônia: $y=$ $-11.43+0.017 x, r^{2}=0.95$, em que y: fluxo de ions $\left(\mathrm{mmol} \mathrm{kg}^{-1} \mathrm{~h}^{-1}\right)$ ou excreção de amônia $\left(\mathrm{mg} \mathrm{kg}^{-1} \mathrm{~h}^{-1}\right)$ e x: densidade de carga (g). Portanto, o aumento da densidade de carga aumenta a perda de ions, mas reduz a excreção de amônia durante o transporte de jundiá, indicando possibilidade de acúmulo de amônia no corpo.

Palavras-chave: transporte de peixes, ionorregulação, densidade de carga.

\section{INTRODUCTION}

Silver catfish Rhamdia quelen is the native species most frequently raised in southern Brazil (BALDISSEROTTO, 2009) because is well adapted for cultivation even in the winter (GARCIA et al., 2008). Commercial fish production requests an appropriate management during transportation. Water quality and physiological responses must be observed to avoid losses during this process and reduce posterior contamination with opportunist pathogens due to the stress occasioned by this procedure (CARNEIRO et al., 2009).

Transport in plastic bags is the most used system for fish transport in Brazil (GOMES et al., 1999; GOLOMBIESKI et al., 2003; CARNEIRO et al., 2009). The high transport cost request the use of a small amount of water and the highest load density possible, which cause accumulation of metabolites and deteriorate water quality (GOLOMBIESKI et al., 2003). Ammonia is the dominant end product of nitrogen metabolism in most teleosts, including

\footnotetext{
'Laboratório de Qualidade da Água, Instituto de Oceanografia, Universidade Federal do Rio Grande (FURG), 96210-030, Rio Grande, RS, Brasil. E-mail: garcia_log@hotmail.com. Corresponding author.

"Departamento de Medicina Veterinária, Universidade de Passo Fundo (UPF), Passo Fundo, RS, Brasil.

IIIPrograma de Pós-graduação em Zootecnia, Departamento de Fisiologia e Farmacologia, Universidade Federal de Santa Maria (UFSM), Santa Maria, RS, Brasil. 
silver catfish (GOLOMBIESKI et al., 2013), and is toxic at low concentrations (IP \& CHEW, 2010). During transport the concentration of this metabolite increases and may be a potential risk that influences fish survival and duration of transport (GOMES et al., 1999; GOLOMBIESKI et al., 2003; CARNEIRO et al., 2009).

Studies regarding silver catfish transportation analyzed the effect of salt addition in the water of transport, load density, temperature, time of transport and load density (GOMES et al., 1999; GOLOMBIESKI et al., 2003; CARNEIRO et al., 2009). The stress of transport is associated with catecholamine liberation, which increases branchial perfusion and consequently increases ion loss to the water (RANDALL \& PERRY, 1992). Measurements of net ion fluxes provide a good correlation with stress of transport in Arapaima gigas (pirarucu) (GOMES et al., 2006), Carnegiella strigata (marbled hatchetfish), Paracheirodon axelrodi (cardinal tetra) (GOMES et al., 2008; 2009) and silver catfish (PARODI et al., 2014). Therefore, the objective of this study was to verify net ion fluxes and ammonia excretion in silver catfish during the transport in plastic bags at different load densities.

\section{MATERIALS AND METHODS}

Silver catfish juveniles $\quad(76.6 \pm 0.7 \mathrm{~g})$ were obtained from the fish culture sector at the Universidade de Passo Fundo, Rio Grande do Sul state, South Brazil. These juveniles were collected from earth tanks and maintained in 1000L tanks in the laboratory for two days. Feeding was discontinued $24 \mathrm{~h}$ prior transportation. After this period, fish were placed in plastic bags $(15 \mathrm{~L})$ with $7.7 \mathrm{~L}$ water and $2.3 \mathrm{~L}$ of pure oxygen. Three loading densities were used: 221,286 and $365 \mathrm{~g} \mathrm{~L}^{-1}$ (three replicates each). Juveniles were transported for $5 \mathrm{~h}$ in pavemented roads $(294 \mathrm{~km})$. The loading densities tested were similar to those tested by CARNEIRO et al. (2009) and the time of transport is the most commonly observed in the transport of this species in the Rio Grande do Sul state. To analyze the transport of silver catfish in a different size range, the size used in the present study were higher than those used by GOLOMBIESKY et al. (2003) and CARNEIRO et al. (2009).

Net ion fluxes and ammonia excretion were calculated according to the equation: Jnet $=\mathrm{V}\left(\left[\right.\right.$ ion $\left._{1}\right]-$ $\left.\left[\mathrm{ion}_{2}\right]\right) .(\mathrm{Mt})^{-1}$, where $\left[\mathrm{ion}_{1}\right]$ and $\left[\mathrm{ion}_{2}\right]$ are the ion or ammonia concentrations in the water of transport at the beginning and end of the transport period, respectively, $\mathrm{V}$ is the water volume (in $\mathrm{L}$ ), $\mathrm{M}$ is the mass of the fish (in $\mathrm{kg}$ ) and $\mathrm{t}$ is the duration of the transport (in h). Water quality parameters (hardness, alkalinity, ammonia, nitrite, temperature, dissolved oxygen and $\mathrm{pH}$ ) in the plastic bags were monitored at the start and at the end of the transport period. Water $\mathrm{pH}$ was monitored with a DMPH-2 (Digimed, São Paulo, Brazil) pHmeter. Total ammonia and water hardness levels were verified following EATON et al. (2005) and un-ionized ammonia levels were calculated according to the method of COLT (2002). Dissolved oxygen and temperature were measured with a YSI oxygen meter (model Y5512). Levels of total alkalinity and nitrite were determined as described by BOYD (1998). Chloride levels were determined according to ZALL et al. (1956), and $\mathrm{Na}^{+}$ and $\mathrm{K}^{+}$levels were determined with a B262 flame spectrophotometer (Micronal, São Paulo, Brazil). Standard solutions were made with analytical-grade reagents (Vetec or Merck) dissolved in deionized water, and standard curves of each ion to be tested were made for five different concentrations.

Data were reported as mean \pm SEM. The homogeneity of variances among groups was tested with the Levene test. Water quality parameters in all treatment groups were compared by one-way ANOVA followed by Tukey's test. The analysis of the relationships between net ion fluxes and ammonia excretion and loading density were performed using the Sigma Plot 11.0 software. All tests were performed with the Software Statistica 5.1 (1997; StatSoft Inc., Tulsa, OK, USA). The minimum significance level was set at $\mathrm{P}<0.05$.

\section{RESULTS}

There was a significant positive relationship between net ion fluxes, total and unionized ammonia and loading density, but negative relationship between ammonia excretion and loading density. These relationships are demonstrated by the following equations: $\mathrm{Na}+: \mathrm{y}=$ -24.5-0.27x, r2=0.99 (Figure 1A), Cl-: $\mathrm{y}=40.2-$ $0.61 \mathrm{x}, \mathrm{r} 2=0.98$ (Figure 1B), $\mathrm{K}+\mathrm{x}: \mathrm{y}=8.0-27.6 \mathrm{x}$, $\mathrm{r} 2=0.94$ (Figure 1C); ammonia excretion: $y=-$ $6.57-1.25 \mathrm{x}, \mathrm{r} 2=0.91$ (Table 1); total ammonia $\mathrm{y}=6.68+0.009 \mathrm{x}, \quad \mathrm{r} 2=0.92 ;$ unionized ammonia $\mathrm{y}=-0.82+0.0046 \mathrm{x}, \mathrm{r} 2=0.86$, where $\mathrm{y}$ : net ion flux (mmol kg-1 h-1) or ammonia excretion (mg kg-1 $\mathrm{h}-1)$, total and unionized ammonia (mg L-1) and $\mathrm{x}$ : loading density (g L-1). Dissolved oxygen levels, total ammonia and un-ionized ammonia were 


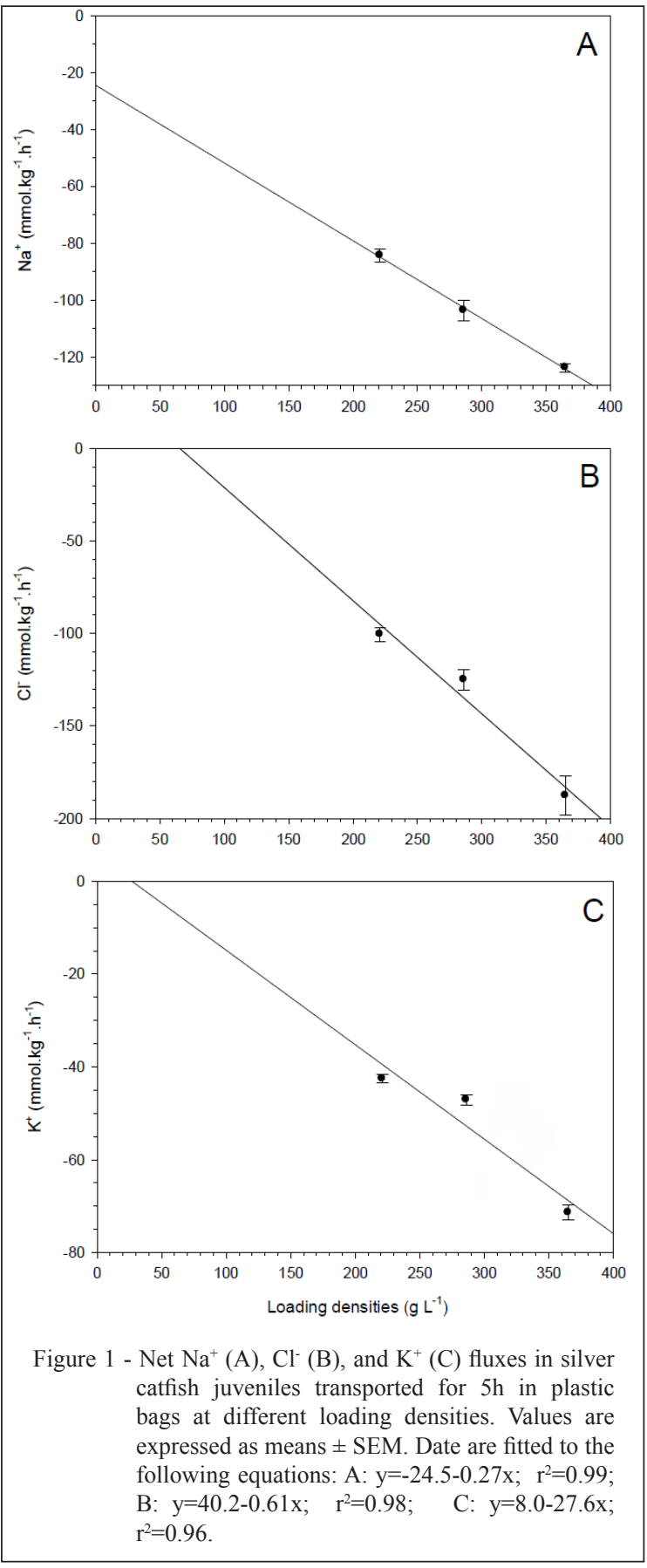

significantly higher and $\mathrm{pH}$ lower at the end of the transport. The other water parameters were not affected significantly by transportation (Table 2).

\section{DISCUSSION}

Transporting fish is very important for fish culture and monitoring water quality is essential to the success of this operation. This situation cause stress, which increases cortisol levels in silver catfish (BARCELLOS et al., 2001; 2003; 2004) and stimulates glycogenesis, gluconeogenesis, protein catabolism and ammonia production (RANDALL \& TSUI, 2002; IP \& CHEW, 2010). Silver catfish net $\mathrm{Na}^{+}, \mathrm{K}^{+}$and $\mathrm{Cl}^{-}$effluxes through the transport increased with the increase of loading density, demonstrating that high loading density increases ionoregulatory stress in this species. Loss of these ions was also demonstrated in previous studies about silver catfish transportation (BECKER et al., 2012; 2013; PARODI et al., 2014; ZEPPENFELD et al., 2014) and is a good parameter to indicate stress in freshwater fish because stress increases gill ventilation rate, which increased ion branchial efflux (McDONALD et al., 1991).

In the present study the ammonia levels in the water of transport increased due to excretion via gills. Unionized ammonia values observed even at the highest load density at the end of experiment were very low because water $\mathrm{pH}$ reduced significantly and the percentage of unionized ammonia decreased at acidic $\mathrm{pH}$ (COLT, 2002). Ammonia excretion values through the $5 \mathrm{~h}$ transport of silver catfish juveniles decreased with the increase of the loading density. Ammonia excretion values also decrease with the increase of loading density $\left(75-350 \mathrm{~g} \mathrm{~L}^{-1}\right)$ in silver catfish juveniles (23-28g) transported for $5 \mathrm{~h}\left(24.6^{\circ} \mathrm{C}\right)$ (CARNEIRO et al., 2009). This decrease on ammonia excretion may have occurred because the increase of water

Table 1 - Ammonia excretion in silver catfish as a function of load density and transport time. The relationships are described by the following equation: $y=-6.57-1.25 \mathrm{x}$, $\mathrm{r}^{2}=0.91$ (present study); where $y=$ ammonia excretion $\left(\mathrm{mg} \mathrm{kg}^{-1} \mathrm{~h}^{-1}\right)$ and $\mathrm{x}=$ load density $\left(\mathrm{g} \mathrm{L}^{-1}\right)$.

\begin{tabular}{lll}
\hline $\begin{array}{c}\text { Load density } \\
\left(\mathrm{g} \mathrm{L}^{-1}\right)\end{array}$ & Weight fish ${ }^{-1}(\mathrm{~g})$ & $\begin{array}{l}\text { Ammonia } \\
\text { excretion } \\
\left(\mathrm{mg} \mathrm{kg}^{-1} \mathrm{~h}^{-1}\right)\end{array}$ \\
\hline $100^{1}$ & 5.8 & -34.72 \\
$75^{2}$ & 23.5 & -17.25 \\
$150^{2}$ & 23.5 & -15.75 \\
$250^{2}$ & 23.5 & -16.39 \\
$350^{2}$ & 23.5 & -14.56 \\
$221^{3}$ & 76.6 & -7.99 \\
$286^{3}$ & 76.6 & -6.24 \\
$365^{3}$ & 76.6 & -5.55 \\
$162^{4}$ & 3.0 & -17.85 \\
$169^{5}$ & 301.2 & -42.60 \\
\hline
\end{tabular}

${ }^{1}$ GOMES et al., 1999; ${ }^{2}$ CARNEIRO et al., 2009; ${ }^{3}$ GARCIA et al. (present study); ${ }^{4}$ PARODI et al., in press; ${ }^{5}$ BECKER et al., 2012 .

Ciência Rural, v.45, n.10, out, 2015. 
Table 2 - Physicochemical parameters of transport water in the experimental plastic bags before and after transport simulation at different load density. Data are reported as mean \pm SEM. Different letters indicate significant differences between different load density in total or unionized ammonia levels $(\mathrm{P}<0.05)$.

\begin{tabular}{|c|c|c|c|c|}
\hline \multirow{2}{*}{ Physicochemical Parameters } & \multirow{2}{*}{ Initial values } & \multicolumn{3}{|c|}{---The end of transport simulation (load density in $\mathrm{g} \mathrm{L}^{-1}$ ) - } \\
\hline & & 221 & 286 & 365 \\
\hline $\mathrm{pH}$ & $6.8 \pm 0.2^{\mathrm{a}}$ & $5.6 \pm 0.4^{\mathrm{b}}$ & $5.4 \pm 0.1^{\mathrm{b}}$ & $5.1 \pm 0.2^{\mathrm{b}}$ \\
\hline Dissolved oxygen $\left(\mathrm{mg} \mathrm{L}^{-1}\right)$ & $6.1 \pm 0.3^{\mathrm{a}}$ & $11.4 \pm 0.9^{\mathrm{b}}$ & $10.0 \pm 0.7^{\mathrm{b}}$ & $8.6 \pm 0.5^{\mathrm{c}}$ \\
\hline Temperature $\left({ }^{\circ} \mathrm{C}\right)$ & $23.5 \pm 0.2$ & $25.0 \pm 2.5$ & $24.6 \pm 0.4$ & $23.8 \pm 0.2$ \\
\hline Hardness $\left(\mathrm{mg} \mathrm{CaCO}_{3} \mathrm{~L}^{-1}\right)$ & $17.8 \pm 0.1$ & $18.5 \pm 3.8$ & $19.1 \pm 0.5$ & $19.9 \pm 0.3$ \\
\hline Alkalinity $\left(\mathrm{mg} \mathrm{CaCO}_{3} \mathrm{~L}^{-1}\right)$ & $14.5 \pm 0.1$ & $12.0 \pm 2.0$ & $11.8 \pm 0.2$ & $11.5 \pm 0.1$ \\
\hline Nitrite $\left(\mathrm{mg} \mathrm{L}^{-1}\right)$ & $0.001 \pm 0.001$ & $0.005 \pm 0.002$ & $0.005 \pm 0.004$ & $0.005 \pm 0.002$ \\
\hline Total ammonia $\left(\mathrm{mg} \mathrm{L}^{-1}\right)$ & $0.07 \pm 0.01^{\mathrm{a}}$ & $8.9 \pm 1.7^{\mathrm{b}}$ & $9.0 \pm 1.1^{\mathrm{b}}$ & $10.2 \pm 0.8^{\mathrm{b}}$ \\
\hline Unionized ammonia $\left(\mu \mathrm{g} \mathrm{L}^{-1}\right)$ & $0.22 \pm 0.03^{\mathrm{a}}$ & $2.01 \pm 0.38^{\mathrm{b}}$ & $1.25 \pm 0.15^{\mathrm{c}}$ & $0.67 \pm 0.05^{\mathrm{c}}$ \\
\hline
\end{tabular}

ammonia levels decreases the plasma-water ammonia gradient next to the external surface of the gills, which impairs ammonia excretion and can increase ammonia accumulation (RANDALL \& TSUI, 2002; WRIGHT \& WOOD, 2012).

\section{CONCLUSION}

Silver catfish can be transported for $5 \mathrm{~h}$ with a loading density up to $365 \mathrm{~g} \mathrm{~L}^{-1}$, but the use of lower densities reduces body ion loss and probably ammonia accumulation.

\section{BIOETHICS AND BIOSSECURITY COMMITTEE}

The methodology of this experiment was approved by the Ethical and Animal Welfare Committee of the Universidade Federal de Santa Maria (Process n. 046/2010).

\section{ACKNOWLEDGEMENTS}

L.O. Garcia, B. Baldisserotto and L.J.G. Barcellos received Conselho Nacional de Desenvolvimento Científico e Tecnológico $(\mathrm{CNPq})$ research fellowships.

\section{REFERENCES}

BALDISSEROTTO, B. Piscicultura continental no Rio Grande do Sul: situação atual, problemas e perspectivas para o futuro. Ciência Rural, v.39, p.291-299, 2009. Available from: <http:// www.scielo.br/pdf/cr/v39n1/a46cr443.pdf $>$. Accessed: Sept. 24, 2014. doi: 10.1590/S0103-84782008005000046.

BARCELLOS, L.J.G. et al. Plasma levels of cortisol and glucose in response to capture and tank transference in Rhamdia quelen (Quoy \& Gaimard), a South American Catfish. Aquaculture Research, v.32, p.121-123, 2001. Available from: <http:// onlinelibrary.wiley.com/doi/10.1046/j.1365-2109.2001.00539.x/ pdf $>$. Accessed: Sept. 24, 2014. doi: 10.1046/j.13652109.2001.00539.x.
BARCELLOS, L.J.G. et al. Haematological and biochemical characteristics of male jundiá (Rhamdia quelen Quoy \& Gaimard Pimelodidae ) and hormonal and biochemical changes after acute stress. Aquaculture Research, v.34, p.1465-1469, 2003. Available from: $<$ http://onlinelibrary.wiley.com/doi/10.1111/j.1365-2109.2003.00972.x/ full>. Accessed: Sept. 24, 2014. doi: 10.1111/j.1365-2109.2003.00972.x.

BARCELLOS, L.J.G. et al. Hematological changes in jundiá (Rhamdia quelen Quoy \& Gaimard Pimelodidae) provoked by usual aquaculture practices, with emphasis on immunosuppressive effects. Aquaculture, v.237, p.229-236, 2004. Available from: <http:// ac.els-cdn.com/S0044848604002200/1-s2.0-S0044848604002200main.pdf? tid=ec3f5418-43fc-11e4-a32b-00000aacb35f\&acdnat= 1411571610_9b8b8d6fe4327a95434b45b209e9ccb2>. Accessed: Set. 24,2014 . doi: 10.1016/j.aquaculture.2004.03.026.

BECKER, A.G. et al. Transportation of silver catfish, Rhamdia quelen, in water with eugenol and the essential oil of Lippia alba. Fish Physiology and Biochemistry, v.38, p.789-796, 2012. Available from: $<$ http://link.springer.com/article/10.1007\%2Fs10695-011-9562-4>. Accessed: Sept. 24, 2014. doi: 10.1007/s10695-011-9562-4.

BECKER, A.G. et al. Efficacy of eugenol and the methanolic extract of Condalia buxifolia during the transport of the silver catfish Rhamdia quelen. Neotropical Ichthyology, v.11, p.675-681, 2013. Available from: <http://www.scielo.br/pdf/ ni/v11n3/1679-6225-ni-11-03-00675.pdf>. Accessed: Sept. 24, 2014. doi: 10.1590/S1679-62252013000300021.

BOYD, C.E. Water quality for pond aquaculture. Research and Development Series. Alabama: (International Center for Aquaculture and Aquatic Environments, Auburn University), 1998. Series n.43, p.1-37.

CARNEIRO, P.C.F. et al. Transport of jundiá Rhamdia quelen juveniles at different loading densities: water quality and blood parameters. Neotropical Ichthyology, v.7, n.2, p.283-288, 2009. Available from: <http://www.scielo.br/pdf/ni/v7n2/a21v7n2.pdf $>$. Accessed: Sept. 24, 2014. doi: 10.1590/S1679-62252009000200021.

COLT, J. List of spreadsheets prepared as a complement to the book fish hatchery management. In: WEDEMEYER G.A. (Ed.). 2.ed. Bethesda: American Fisheries Society Publications, 2002. 751p.

EATON, A.D. et al. Standard methods for the examination of water and wastewater. 21.ed. Washington, DC: American Public Health Association, 2005. 1325p. 
GARCIA, L.O. et al. Freshwater temperature in the state of Rio Grande do Sul, Southern Brazil, and its implication for fish culture. Neotropical Ichthyology, v.6, p.275-281, 2008. Available from: <http://www.scielo. br/pdf/ni/v6n2/16.pdf $>$. Accessed: Sept. 24, 2014. doi: 10.1590/S167962252008000200016.

GOLOMBIESKI, J.I. et al. Transport of silver catfish (Rhamdia quelen) at different times, load densities, and temperatures. Aquaculture, v.216, p.95-102, 2003. Available from: $<$ http://www. sciencedirect.com/science/article/pii/S0044848602002569\#>. Accessed: Sept. 24, 2014. doi: 10.1016/S0044-8486(02)00256-9.

GOLOMBIESKI, J.I. et al. Nitrogenous and phosphorus excretions in juvenile silver catfish (Rhamdia quelen) exposed to different water hardness, humic acid, and $\mathrm{pH}$ levels. Fish Physiology and Biochemistry, v.39, p.837-849, 2013. Available from: <http:// http://download.springer.com/static/pdf/209/art\%253A10.1007\% 252Fs10695-012-9744-8.pdf?auth66=1411754746_19f1bf55769 6355916a3cb209614f254\&ext=.pdf>. Accessed: Sept. 24, 2014. doi: 10.1007/s10695-012-9744-8.

GOMES, L.C. et al. Effect of salt in the water of transport on survival and $\mathrm{Na}^{+}$and $\mathrm{K}^{+}$body levels in fingerlings of silver catfish Rhamdia quelen (Pimelodidae). Journal of Applied Aquaculture, v.9, p.1-9, 1999. Available from: $<$ http://www.tandfonline.com/doi/abs/10.1300/ J028v09n04 01?journalCode=wjaa20\#.UILPF1CThPo $>$. Accessed: Sept. 24, 2014. doi: 10.1300/J028v09n04_01.

GOMES, L.C. et al. Use of salt during transportation of air breathing pirarucu juveniles (Arapaima gigas) in plastic bags. Aquaculture, v.256, p.521-528, 2006. Available from: <http://ac.els-cdn.com/ S0044848606001013/1-s2.0-S0044848606001013-main.pdf? tid $=$ d8fffobe-2f63-11e3-988c-00000aab0f26\&acdnat $=13811593$ 44_4ae4cf1f0f1836a15b528a6 ebbb9a84b>. Accessed: Sept. 24, 2014. doi: 10.1016/j.aquaculture.2006.02.004.

GOMES, L.C. et al. Using Efinol L during transportation of marbled hatchetfish, Carnegiella strigata (Günther). Aquaculture Research, v.39, p.1292-1298, 2008. Available from: <http://onlinelibrary. wiley.com/doi/10.1111/j.1365-2109.2008.01993.x/pdf>. Accessed: Sept. 24, 2014. doi: 10.1111/j.1365-2109.2008.01993.x.

GOMES, L.C. et al. Benefits of using the probiotic Efinol L during transportation of cardinal tetra, Paracheirodon axelrodi (Schultz), in the Amazon. Aquaculture Research, v.40, p.157-165, 2009. Available from: <http://onlinelibrary.wiley.com/ doi/10.1111/j.1365-2109.2008. 02077.x/pdf>. Accessed: Sept. 24, 2014. doi: 10.1111/j.1365-2109.2008. 02077.x.
IP, Y.K.; CHEW, S.F. Ammonia production, excretion, toxicity, and defense in fish: a review. Frontiers in Physiology, v.1, p.120, 2010. Available from: <http://www.ncbi.nlm.nih.gov/pmc/ articles/PMC3059970/pdf/fphys-01-00134.pdf>. Accessed: Sept. 24, 2014. doi: 10.3389/fphys.2010.00134.

McDONALD, D.G. et al. Gill design in freshwater fishes: interrelationships among gas exchange, ion regulation, and acid-base regulation. Physiological Zoology, v.64, p.103-123, 1991. Available from: <http://www.jstor.org/ discover/10.2307/30158515>. Accessed: Sept. 24, 2014.

PARODI, T.V. et al. Anesthetic activity of the essential oil of Aloysia triphylla and effectiveness in reducing stress during transport of albino and grey strains of silver catfish, Rhamdia quelen. Fish Physiology and Biochemistry, v.40, p.323-334, 2014. Available from: <http:// link.springer.com/article/10.1007\%2Fs 10695-013-9845-Z>. Accessed: Sept. 24, 2014. doi: 10.1007/s10695-013-9845-z.

RANDALL, D.J.; PERRY, S.F. Catecholamines. In: HOAR, W.S. et al. (Eds.). Fish physiology. San Diego: Academic, 1992. p.255-300. Available from: $<$ http://www.sciencedirect.com/ science/article/pii/S1546509808600114>. Accessed: Sept. 24, 2014. doi: 10.1016/S1546-5098(08)60011-4.

RANDALL, D.J.; TSUI, T.K.N. Ammonia toxicity in fish. Marine Pollution Bulletin, v.45, p.17-23, 2002. Available from: <http:// www.sciencedirect.com/science/article/pii/S0025326X02002278\#>. Accessed: Sept. 24, 2014. doi: 10.1016/S0025-326X(02)00227-8.

WRIGHT,P.A.;WOOD,C.M. Seventhingsfishknowaboutammonia and we don't. Respiratory Physiology and Neurobiology, v.184, p.231-240, 2012. Available from: <http://www.sciencedirect.com/ science/article/pii/S1569904812001942\#>. Accessed: Sept. 24, 2014. doi: 10.1016/j.resp.2012.07.003.

ZALL, D.M. et al. Photometric determination of chlorides in water. Analytical Chemistry, v.28, p.1665-1678, 1956. Available from: <http://pubs.acs.org/doi/pdf/10.1021/ac60119a009>. Accessed: Sept. 24, 2014.

ZEPPENFELD, C.C. et al. Physiological and biochemical responses of silver catfish, Rhamdia quelen, after transport in water with essential oil of Aloysia triphylla (L'Herit) Britton. Aquaculture, v.418-419, p.101-107, 2014. Available from: $<$ http://www.sciencedirect.com/science/article/pii/ S004484861300522X>. Accessed: Sept. 24, 2014. doi: 10.1016/j.aquaculture.2013.10.013. 